\title{
A Comparative Study of Economic Growth in the West African States
}

\author{
Ndife Chinelo Franca \\ Department of Business Administration \& Management, School of Business Studies, Federal Polytechnic, Oko, Nigeria
}

Email address:

Chinelo.Ndife@yahoo.com

\section{To cite this article:}

Ndife Chinelo Francah. A Comparative Study of Economic Growth in the West African States. Journal of World Economic Research. Vol. 6, No. 6, 2017, pp. 75-79. doi: 10.11648/j.jwer.20170606.12

Received: December 18, 2017; Accepted: January 2, 2018; Published: January 19, 2018

\begin{abstract}
A slowdown in the pace of activity has been observed in most ECOWAS countries. Nigeria which is the biggest economy in African managed to struggle out of recently entered recession this year 2017. In all these there is need to critically examine if there has been a significant economic growth in West Africa within the study period, especially in the face of several regional economic integration and treaties existence in West Africa. The Analysis of Variance technique was used to test to variations across the selected countries (column) and over the years (rows). The results of this study have been presented. The result shows that economic growth variables significantly vary across the selected countries but are significantly the same over the years. This implies that economic growth have over the study period been stagnant. There is statistically significant variation in GDP of selected countries but the GDP of the respective countries do not seem to change over the years. There is no significant variation in GDP growth over the years and across the countries. This paper therefore concludes that the West African States and the selected countries in particular have only witnessed a steady growth rate over the years and little variation in countries economic growth within the study period. Furthermore, due to economic integration that is fully functional in the area, economic growth may have been made stable by the existence of common economic policies.
\end{abstract}

Keywords: GDP, Economic Growth, West African Economy, GDP Growth Rate, GDP Per Capita

\section{Introduction}

Economic activity in sub-Saharan Africa has been said to weaken markedly with a large variation in country circumstances with regional growth falling to $3 \frac{1}{2}$ percent in 2015 which was the lowest level in the past 15 years, and is set to decelerate further in 2016 to 3 percent - well below the 5 to 7 percent range experienced over the past decade [1].

The sole objective of creating regional bodies was to take advantage of economies of scale in production and consumption for effective and efficient regional integrations, and in the long run ascertain economic independence. In West Africa, there are three regional bodies identified as explicitly concerned with the promotion of intra-regional trade glows: The Economic Community of West African States (ECOWAS), Communuaute Economique de l'Afrique del' Ouest (CEAO) and MANO River Union (MARIUN). During the last few decades, there has been a great deal of momentum towards regional integration, inspired by the growing awareness of globalization, increasing homogeneity in issues relating to fiscal, financial and technical barriers to trade. These as well as the rapid growth in scientific and technological innovations are all among factors that underlay the importance and need for the various regional cooperation schemes that have come into existence since World War II [2].

In 2015, economic growth in West Africa was 4.2 per cent, down from 6.1 per cent in 2014 as a result of drop in regional growth resulted mainly from the fall in primary commodity prices, in particular oil. The sharp drop in the price of oil which lost over half of its value in under a year, has highlighted the fragile nature of the foundations of West Africa's growth, which is highly dependent on primary commodity exports. A slowdown in the pace of activity has been observed in most ECOWAS countries.

Public debt, in proportion to the GDP of ECOWAS, rose to 21 per cent in 2015, up from 19.3 per cent in 2014 , but well below the critical threshold of 70 per cent set under the 
ECOWAS convergence arrangement. However, this whole situation belies disparities among countries. Following the highly indebted poor countries (HIPC) initiative, most of the countries had their debt ratios below the 70 per cent threshold. Only Cabo Verde (117 per cent) and the Gambia (95.1 per cent), which did not fall under the HIPC initiative, had quite high debts. The debt situation of Ghana also escalated to 72.8 per cent. The debt ratio of Nigeria (11.9 per cent) was the lowest, followed by Niger ( 23.5 per cent) and Benin (25.3 per cent).

In 2017 Nigeria which is the biggest economy in African managed to struggle out of recession recently entered in 2016. In all these there is need to critically examine if there has been a significant economic growth in West Africa within the study period.

\section{Literature Review}

Zahonogo [3] investigated how trade openness affects economic growth in developing countries, with a focus on sub-Saharan Africa (SSA). The study used a dynamic growth model with data from 42 Sub Sahara African (SSA) countries covering 1980 to 2012 and employed the Pooled Mean Group estimation technique, which is appropriate for drawing conclusions from dynamic heterogeneous panels by considering long-run equilibrium relations. The empirical evidence indicates that a trade threshold exists below which greater trade openness has beneficial effects on economic growth and above which the trade effect on growth declines. The evidence also indicates an inverted U-curve (Laffer Curve of Trade) response, robust to changes in trade openness measures and to alternative model specifications, suggesting the non-fragility of the linkage between economic growth and trade openness for sub-Saharan countries. Our findings are promising and support the view that the relation between trade openness and economic growth is not linear for SSA. Accordingly, SSA countries must have more effective trade openness, particularly by productively controlling import levels, in order to boost their economic growth through international trade.

Agbélénko and Kibet [4] examined empirically the relationship between financial development and economic growth in the West African Economic and Monetary Union (WAEMU) for the period 1981-2010. Using the General Moment Method (GMM), the study found a positively and statistically significant effect of financial development on economic growth and the causality was bidirectional. In addition, primary completion rate, foreign direct investment and real exchange rate contribute positively to economic growth in the region while inflation and openness discourage the economic growth in the region. In order to maintain a sustainable economic growth in those countries under study, the reforms for financial system improvement and education sector should be implemented. The policy makers should pursue target macroeconomic policies that may attract foreign direct investment while controlling for inflation and trade openness.
Danladi [5] empirically explored the issue of the existence of threshold effect in the present relationship between inflation and economic growth in the context of West African economies. The study was imperative due to the superficiality and gaps in the existing literatures in exploring the issue of the existence of threshold effect in determining the relationship between inflation and economic growth in the sub-region in terms coverage of issues, analytical framework and methodology. The study covered four countries in the West African region: Burkina Faso, Ghana, Nigeria and Senegal for the period 1980-2009. The results of the study strongly suggest the existence of a threshold level of $9 \%$ beyond which inflation exerts a negative effect on growth. The West African region should prioritize attention to maintaining a relatively low and stable inflation rate if the goal of attaining steady and rapid economic growth is to be achieved.

Lawanson [6] empirically investigated the relevance of educational and health components of human capital to economic growth, using a panel data from sixteen West African countries over the period 1980 to 2013. GDP per capita was linked to health and education capital while accounting for population growth, physical capital, trade openness, and other growth control variables. To correct for endogeneity and other estimation problems the paper employs Diff-GMM dynamic panel technique. Empirical results show that coefficients of both education and health have positive statistically significant effects on GDP per capita. The paper thus affirms the strong relevance of human capital to economic growth of West Africa and therefore recommended that increased resources and policy initiatives to motivate and enhance access to both health and education by the population should be pursued by policy makers.

Babatunde et al [7] carried out various preliminary tests including descriptive statistics, and stationary tests using Augmented Dickey Fuller (ADF) test among others. The fixed and random effect test was employed to determine the fitness of the model using the Hausman test. The result of the study shows that tax revenue is positively related to GDP and promotes Economic Growth in Africa. It was significant at $5 \%$ level. The study concluded that tax revenue has a significant positive relationship with Gross Domestic Product. Therefore, high and weak levels of taxation are favorable to economic growth as upheld by theeconomic effect of Ibn Khaldun's theory on taxation, which approves the positive impact that lower taxrate have on work, output and economic performance. However, in the midst of harsh economic conditions such as crashing oil prices, rising exchange rates, drop in Naira value, the governments should be ready to develop a comprehensive tax structure or model that will grow, nurture and sustainits tax economic base so as to drive economic performance.

Udo, Effiong and Ogar [8] determined the validity of the Wagner's law and Keynes theory in the sixteen countries that make up West African region using a panel analysis. The result reveals that there is a bidirectional relationship between government spending and economic growth in five West 
African countries, unidirectional causality flowing from government expenditure to economic growth in four countries, while unidirectional causality from economic growth to government expenditure were in two countries. However, there were no causal relationship between government expenditure and economic growth in the remaining five countries in West Africa. Also using different versions of Wagner's law, the study observed that only Goffman version is truly validated in the West African economies given the value of more than one per cent marginal effect of per capita growth on expenditure. Therefore, for the countries that respond to Keynes theory, there is need for appropriate policies with respect to government spending knowing that it affects the level of growth.

Ofori-Abebrese et al [9] examined the relationship between cocoa prices, exchange rate and economic growth using time series data for the period 1980 to 2011. Using autoregressive distributed lag (ARDL) modeling approach. The study revealed that higher cocoa price reduces long-run economic growth in Ghana but cannot be an important ingredient in short-run growth. In Cote d'Ivoire, it does not play any significant role in both long-run and short-run economic growth and that increases in cocoa exports rather enhance economic growth of the two countries. Appreciation of the Communaute Financiere Africaine (CFA) franc enhances economic growth but that of the Ghana Cedi is only in the short-run. Higher rates of inflation reduce economic growth of Ghana but enhance that of Cote d'Ivoire. Improvements in life expectancy augment economic growth in Ghana but reduce that of Cote d'Ivoire.

Jalloh [10] investigated the nexus between natural resource endowment and economic growth using a sample of West African countries. The study adopted a Barrow-type growth model to analyse the impact of natural resource wealth on economic growth using a dynamic panel estimation technique that employed relevant data from West African Countries. The results show that natural resource endowments have very minimal impact in terms of promoting economic growth in West Africa, more so in resource rich countries. The result also shows that a $10 \%$ increase in natural resource export reduces growth in income per capita by approximately $0.4 \%$. The author argued that part of the factors explaining this finding amongst others; include high corruption in the public sector as well as the frequency of civil conflicts in resource rich economies of West Africa. For the natural resources of the region to fully benefit its citizens, these countries require, urgently, to improve management of natural resource export revenues and to apply effective policy measures to eradicate/ mitigate incidences of rampant corruption in the public sector.

Agbonkhese and Adekola [2] ascertained how regional economic integration has impacted on the growth of the Nigerian economy as a member of ECOWAS and thus assessed the need for regional economic integration in developing countries. the study used gross domestic product as a stable function which is dependent on a number of economic factors like export, import and balance of trade and relying on the ordinary least squares method; the study covers the period 1970 to 2008 . The result of the study indicated that both import and balance of trade had positive linear relationship with gross domestic product, contrary to export which has a negative relationship with the nation's output. The implication of the result is that imports and balance of trade in regionally integrated markets have powerful influence on the nation's output and recommends that to achieve greater macroeconomic goals from regionally integrated markets, there is need to prudently manage import and export to achieve favourable balance of trade and balance of payments through diversifying the export economy predicated on a strong production base.

Ogujiuba \& Jumare [11] focused on the Challenges facing Sub-Saharan African countries in achieving the Millennium Development Goals (MDGs). This was discussed after revealing growth in GDP and inequality trends in SubSaharan Africa. The authors argued that it was evident that many countries in Sub-Saharan Africa are unlikely to achieve their MDG targets due to persistence of poverty and other challenges such as corruption and mal-administration of funds. Moreover, the required growth to substantially reduce poverty is too high by international standards. The concluded that redistribution of the growth increment of income is more likely to be effective in reducing poverty than growth in GDP alone. Therefore while growth in GDP may be prone to poverty reduction, it should be complemented with policies to ensure investment and broad participation, reduce violence, root out corruption and increase investment in infrastructure. The paper recommends that development strategies must take into consideration national realities in each country rather than adopting targets and policies from the western world.

Abdullahi, Safiyanu and Soja [12] analyzed the relationship between international trade and economic growth in West Africa from 1991-2011 using panel data of 16 out of 17 countries in the region. The result of the study shows that a one percent rise in export variable will lead to growth of GDP by 5.11 percent. Import on the other hand has positive but insignificant impact on GDP growth. The study also found that foreign exchange has negative impact on GDP growth and concluded that exports impact positively on economic growth of the region and recommended that West African countries should encourage indigenous enterprise for export promotion and import substitution.

\section{Research Method}

The study carries out a comparative study of economic growth in selected countries in West Africa. The countries include Nigeria, Ghana, Mali and Benin republic. The study employs Gross Domestic product (GDP), GDP per capita and GDP growth in the selected West African Countries. The Analysis of Variance technique was used to test to variations across the selected countries (column) and over the years (rows). The study employed the ANOVA tool found in excel data analysis tool pak as explained in Igweze \& Etaga [13]. 


\section{Results and Discussion of Findings}

Table 1. ANOVA Result for Countries GDP

\begin{tabular}{llllll}
\hline Source of Variation & SS & $\boldsymbol{d f}$ & $\boldsymbol{M S}$ & $\boldsymbol{F}$ & \multicolumn{1}{c}{$\boldsymbol{P}$-value } \\
\hline Years & $5.43 \mathrm{E}+22$ & 9 & $6.04 \mathrm{E}+21$ & 1.183289 & 0.344568 \\
Countries & $9.6 \mathrm{E}+23$ & 3 & $3.2 \mathrm{E}+23$ & 62.7339 & $2.71 \mathrm{E}-12$ \\
Error & $1.38 \mathrm{E}+23$ & 27 & $5.1 \mathrm{E}+21$ & & 2.960351 \\
Total & $1.15 \mathrm{E}+24$ & 39 & & \\
\hline
\end{tabular}

Table 1 presents the analysis of variance result for GDP of countries. The p-value $(0.3446)$ which is greater than 0.05 level of significance reveals that there is no significant difference in the GDP of countries over the years. There is however, a significant difference in the GDP across the selected countries as the p-value. This means that the GDP of the studied West African states are not statistically the same.

Table 2. GDP Per Capita.

\begin{tabular}{lllllll}
\hline Source of Variation & $\boldsymbol{S S}$ & $\boldsymbol{d f}$ & $\boldsymbol{M S}$ & $\boldsymbol{F}$ & $\boldsymbol{P}$-value & $\boldsymbol{F}$ crit \\
\hline Years & $6.56 \mathrm{E}+22$ & 9 & $7.29 \mathrm{E}+21$ & 1 & 0.46353 & 2.250131 \\
Countries & $5.84 \mathrm{E}+24$ & 3 & $1.95 \mathrm{E}+24$ & 266.8979 & $3.59 \mathrm{E}-20$ & 2.960351 \\
Error & $1.97 \mathrm{E}+23$ & 27 & $7.29 \mathrm{E}+21$ & & & \\
Total & $6.1 \mathrm{E}+24$ & 39 & & & & \\
\hline
\end{tabular}

Table 2 presents the analysis of variance result for GDP per capita of the selected West African countries. The result shows that GDP per capita significantly varies across the selected countries as the p-value is far less than 0.05 . The result also shows that GDP per capita does not significantly vary across the years.

Table 3. GDP growth rate.

\begin{tabular}{llllll}
\hline ANOVA & & & & & \\
\hline Source of Variation & SS & $\boldsymbol{d f}$ & MS & F & P-value \\
\hline Years & 48.06966 & 9 & 5.341074 & 0.728562 & 0.679278 \\
Countries & 46.27751 & 3 & 15.42584 & 2.104198 & 0.123123 \\
Error & 197.9364 & 27 & 7.330979 & & \\
Total & 292.2836 & 39 & & & \\
\hline
\end{tabular}

Table 3 presents the analysis of variance result for the GDP growth rate across the countries and over the years. The result shows that the GDP growth rate is not significantly different over the years and across the countries, as their pvalues are greater than 0.05 level of significance.

\section{Conclusion}

The results of this study have been presented. The result shows that economic growth variables significantly vary across the selected countries but are significantly the same over the years. This implies that economic growth have over the study period been stagnant. There is statistically significant variation in GDP of selected countries but the GDP of the respective countries do not seem to change over the years. There is no significant variation in GDP growth over the years and across the countries. This paper therefore concludes that the west African States and the selected countries in particular have only witnessed a steady growth rate over the years and little variation in countries economic growth within the study period. Furthermore, due to economic integration that is fully functional in the area, economic growth may have been made stable by the existence of common economic policies.

\section{Appendix}

Table A1. Countries GDP (USD).

\begin{tabular}{lllll}
\hline Year & Nigeria & Ghana & Mali & Benin \\
\hline 2007 & 166451213395.64 & 24758819718 & 8145694632 & 5969535132 \\
2008 & 208064753766.47 & 28526891010 & 9750822511 & 7132787397 \\
2009 & 169481317540.36 & 25977847814 & 10181021770 & 7097198712 \\
2010 & 369062464570.39 & 32174772956 & 10678749467 & 6970240895 \\
2011 & 411743801711.64 & 39566292433 & 12978107561 & 7814081156 \\
2012 & 460953836444.36 & 41939728979 & 12442747897 & 8152554487 \\
2013 & 514966287206.51 & 47805069495 & 12813248725 & 9156748441 \\
2014 & 568498939784.02 & 38616536132 & 14004067516 & 9707432016 \\
2015 & 481066152870.27 & 37543361204 & 12746688962 & 8290986804 \\
2016 & 405082677659.87 & 42689783734 & 14045098238 & 8583031398 \\
\hline
\end{tabular}

Table A2. GDP PER CAPITA (USD).

\begin{tabular}{lllll}
\hline Year & Nigeria & Ghana & Mali & Benin \\
\hline 2007 & 1136.83 & 1090.69 & 595.64 & 706.05 \\
2008 & 1383.89 & 1224.40 & 689.68 & 820.15 \\
2009 & 1097.66 & 1086.77 & 697.02 & 793.45 \\
2010 & 2327.32 & 1312.61 & 708.37 & 757.70 \\
2011 & 2527.94 & 1574.98 & 835.09 & 825.94 \\
2012 & 2755.30 & 1629.80 & 777.35 & 837.95 \\
2013 & 2996.96 & 1814.49 & 777.61 & 915.27 \\
2014 & 3221.68 & 1432.23 & 825.57 & 943.69 \\
2015 & 2655.16 & 1361.11 & 729.72 & 783.95 \\
2016 & 2177.99 & 1513.46 & 780.51 & 789.44 \\
\hline
\end{tabular}


Table A3. GDP GROWTH RATE (\%).

\begin{tabular}{lllll}
\hline Year & Nigeria & Ghana & Mali & Benin \\
\hline 2007 & 6.828 & 4.347 & 3.494 & 5.987 \\
2008 & 6.270 & 9.150 & 4.773 & 4.893 \\
2009 & 6.934 & 4.846 & 4.679 & 2.319 \\
2010 & 7.840 & 7.900 & 5.413 & 2.117 \\
2011 & 4.887 & 14.046 & 3.240 & 2.963 \\
2012 & 4.279 & 9.293 & -0.836 & 4.810 \\
2013 & 5.394 & 7.313 & 2.304 & 7.193 \\
2014 & 6.310 & 3.986 & 7.043 & 6.358 \\
2015 & 2.653 & 3.916 & 5.963 & 2.094 \\
2016 & -1.541 & 3.577 & 5.349 & 3.981 \\
\hline
\end{tabular}

\section{References}

[1] IMF (2016). World Economic and Financial Surveys: Regional Economic Outlook. Sub-Saharan Africa, Time for a Policy Reset.

[2] Agbonkhese, A. O., and Adekola, A. G (2014). Regional Economic Integration In Developing Countries: A Case Study Of Nigeria; A Member Of ECOWAS. European Scientific Journal, vol. 10 (19).

[3] Zahonogo, P. (2017). Trade and economic growth in developing countries: Evidence from sub-Saharan Africa. Journal of African Trade 3 pp. 41-56.

[4] Agbélénko, F. A and Kibet, K. S (2015). Financial development and economic growth in West African Economic and Monetary Union (WAEMU). African Journal of Business Management.

[5] Danladi, J. D (2013). Inflation and Sustainable Output Performance in the West African Sub-Region: The Threshold Effect. American Journal of Economics 2013, 3 (6).
[6] Lawanson, A. O (2015). Economic Growth Experience of West African Region: Does Human Capital Matter? International Journal of Business and Social Science Vol. 6, No. 12.

[7] Babatunde, O. A., Ibukun, A. O and Oyeyemi, O. G (2017) Taxation revenue and economic growth in Africa. Journal of Accounting and Taxation, Vol. 9 (2), pp. 11-22.

[8] Udo, A. B., Effiong, C. E, and Ogar, O. O. (2016). Economic Growth of West African Countries and the Validity of Wagner's Law: A Panel Analysis. Asian Journal of Economics and Empirical Research, Vol. 3, No. 1, 71-83.

[9] Ofori-Abebrese, J., Pickson, R. B. and Ofori-Abebrese, G (2017). Commodity prices, exchange rate and economic growth in West Africa: Case study of Cote d'Ivoire and Ghana. Journal of Development and Agricultural Economics. Vol. 9 (9), pp. 269-277.

[10] Jalloh, M (2013). Natural resources endowment and economic growth: The West African Experience. Journal of Natural Resources and Development, vol. 03 pp. 66-84.

[11] Ogujiuba, K \& Jumare, F (2012). Challenges of Economic Growth, Poverty and Development: Why Are the Millennium Development Goals (MDGs) not Fair to Sub-Saharan Africa? Journal of Sustainable Development; Vol. 5 (12).

[12] Abdullahi, A. O., Safiyanu, S. S. and Soja, T (2016). International Trade And Economic Growth: An Empirical Analysis Of West Africa. IOSR Journal of Economics and Finance, Vol. 7 (2).

[13] Igweze, A. H \& Etaga H. O (2011), Statistical Analyses with Excel, Minitab \& SPSS, Tualas Publisher Asaba. 